American University Washington College of Law

Digital Commons @ American University Washington College of

Law

Articles in Law Reviews \& Other Academic Journals

Scholarship \& Research

1998

Separatism and the Democratic Entitlement

Diane Orentlicher

Follow this and additional works at: https://digitalcommons.wcl.american.edu/facsch_lawrev

Part of the Human Rights Law Commons, International Law Commons, and the Law and Politics Commons 
governments, along with judicial review of constitutionality to make sure that majoritarian decisions do not violate human rights.

\section{SEPARATISM AND THE DEMOCRATIC ENTITLEMENT}

\section{by Diane F. Orentlicher}

That international law does not entitle groups other than colonized peoples-and, perhaps, systematically oppressed groups-to their own state is a familiar claim to international lawyers, so often repeated that it has acquired a sense of canonical force. But recent developments have rendered this claim an increasingly inadequate account of international law relevant to separatist movements. While international law does not generally support the claims of state-seeking groups, contemporary developments may lend some secessionists a new source of legitimacy and have significant-if complex-implications for the resolution of many separatist claims.

The developments I have in mind were chronicled by Thomas Franck in an important article published six years ago in the American Journal of International Law. In that article Franck identified an emerging "democratic entitlement" and described the nascent law this way: "Democracy is on the way to becoming a global entitlement, one that increasingly will be promoted and protected by collective international processes." Although Franck did not suggest that this emerging law has substantial implications for separatist movements, I believe that principles underlying the "democratic entitlement" are scarcely irrelevant to the legitimacy of their claims.

Before I develop this point, it may be helpful first to make clear what I am not claiming. It is not my view that the emerging right to self-government generally privileges separatist claims. On the contrary, considerations relating to democratic theory may point in much the opposite direction. I do, however, disagree with the view that democratic theory is largely, if not wholly, irrelevant to the resolution of separatist claims.

This view is, in fact, commonplace among political theorists. ${ }^{2}$ Whether the issue is how to identify nations that are entitled to their own state or local populations entitled to home rule, many writers claim that "there is no theory for determining when one ... polity ought to end and another begin." Consistent with this view, Franck eschews the inference that the democratic entitlement generally entails the right to choose the territorial boundaries within which self-government should be exercised or the fellow citizens with whom one will practice self-government. ${ }^{4}$

'Professor of Law, Washington College of Law, American University, Washington, DC. This paper draws upon my analysis in Separation Anxiety: International Responses to Ethno-Separatist Claums, 23 YALE J. INT'L L. 1 (1998).

'Thomas M. Franck. The Emerging Right to Democratic Governance, 86 AJL 46 (1992).

${ }^{2}$ See, e.g., Frederick G. Whelan, Prologue: Democratic Theory and the Boundary Problem, in LIBERAL DEMOCRACY, 25 NOMOS 13, 16 (J. Roland Pennock \& John W. Chapman eds., 1983) (asserting that "[b]oundaries comprise a problem . . that is insoluble within the framework of democratic theory."); Richard Briffault, Voting Rights, Home Rule, and Metropolitan Governance: The Secession of Staten Island as a Case Study in the Dilemmas of Local Self-Determination, 92 COLUM. L. REV. 775, 800 (1992) (observing that "the concept of self-government says nothing about who is the "self" that does the governing").

${ }^{3}$ Briffault, supra note 2 , at 801 .

"In his 1992 article, Franck suggested that it is neither "conceptually [nor] strategically helpful-at least at this stage of development-to treat the democratic entitlement as inextricably linked to the claim of minorities to secession." Franck, supra note 1, at 52. Citing the principle of selfdetermination as "the historic root from which the democratic entitlement grew," Franck characterizes 
These scholars are surely correct in claiming that a right to democratic government does not automatically or generally entitle separatists to achieve their aims. Still, it does not follow that the democratic entitlement is irrelevant to separatist claims.

An appeal to common-sense intuition may help make this clear. Suppose that, instead of opposing Quebec's bid to secede, the rest of Canada voted in support of the separatists' claim. Suppose at the same time that residents of Quebec, including all of its significant minority populations, overwhelmingly voted in favor of secession. If, with Franck, we believe that an emerging body of international law "requires democracy to validate governance," I suspect that most of us would conclude that the mutual desire of Canada's citizens to divide should - perhaps must-be honored. To do otherwise would manifestly subject Canada's citizens to government without their consent. And as my colleague Jamie Raskin has written, "the very heart of the democratic idea" is "that governmental legitimacy depends upon the affirmative consent of those who are governed."

The position I have suggested is not as novel as it may seem. For some eighteenthcentury nationalists- the intellectual progenitors of Franck's democratic entitlement-it seemed axiomatic that the right to self-government implied the right to choose one's fellow citizens. The point seemed equally plain to John Stuart Mill:

Where the sentiment of nationality exists in any force, there is a prima facie case for uniting all the members of the nationality under the same government, and a government to themselves apart. This is merely saying that the question of government ought to be decided by the governed. One hardly knows what any division of the human race should be free to do, if not to determine with which of the various collective bodies of human beings they choose to associate themselves.

The argument is elegant in its simplicity: Since democracy is, by definition, government with the consent of the governed, the boundaries of political commitment should be determined in accordance with the principle of consent.

This argument need not imply that the boundaries of states are perennially up for popular reconsideration; the continuing consent of states' citizens can generally be assumed, and indeed this assumption is indispensable to the daily practice of democracy. But if consent is manifestly withdrawn by a significant portion of a state's population, the legitimacy of that state's sovereignty over the rebel population is surely placed in doubt.

Again, let me appeal to common-sense intuition to make this point. It is now established doctrine that alien states may not lawfully impose their rule upon unconsenting peoples. Put differently, international law no longer abides colonization or forcible annexation. But if these forms of nonconsensual rule are incompatible with accepted principles of selfdetermination, surely those same principles are at least challenged by a state's continued assertion of sovereignty over a defined population that has unambiguously and irrevocably rejected its sovereignty.

the principle in terms that assume the boundaries of an established political unit: "Self-determination postulates the right of a people organized in an established territory to determine its collective political destiny in a democratic fashion and is therefore at the core of the democratic entitlement." Id.

IId. at 47.

'Jamie B. Raskin, Legal Aliens, Local Citizens: The Historical, Constitutional and Theoretical Meanings of Alien Suffrage, 141 U. PA. L. REV. 1391, 1444 (1993).

7JOHN STUART MiLL, CONSIDERATIONS ON REPRESENTATIVE GOVERNMENT (1861), quoled in UTILITARIANISM, ON LIBERTY, CONSIDERATIONS ON REPRESENTATIVE GOVERNMENT 392 (1993) (emphasis added). 
I have tried to make the point that Franck's democratic entitlement may have significant implications for separatist claims by invoking the proverbial easy case-a hypothetical situation in which all affected citizens support a separatist claim. But few cases are easy; most separatist claims are contested. When the will of the affected polity is divided, democratic theories are not readily dispositive of contested separatist claims. Even so, theories of democratic government may point to considerations that are relevant to the legitimacy and resolution of such claims, principally because some resolutions may better promote values relating to democratic governance than others. By way of illustration, I would like to explore the implications for separatist claims of two different strands of democratic theory-utilitarianism and republicanism.

A utilitarian justification for democracy claims that self-government is more likely than its alternatives to secure the interests of the greatest number of persons subject to governmental authority. For eighteenth-century utilitarians such as Jeremy Bentham and James Mill, democracy was not an end in itself but a means for maximizing the realization of individuals' interests through aggregation of private preferences. But this justification may begin to fray if a polity is too diverse, at least if its diversity entails significant differences in political choices.

When individuals define their political interests in terms of the well-being of the national group to which they belong, nationalism and utilitarian justifications for democracy may converge to support national separatist movements. Some contemporary theories of national self-determination make precisely this type of argument. Asserting that the wellbeing of individuals is tied to the welfare of the national group to which they belong and which commands their paramount loyalty, some advocates of national self-determination argue that nation states may offer the best assurance of securing the well-being of nations and their members.

Although the republican tradition offers a significantly different vision of democracy than utilitarianism, the former, like the latter, may provide support for at least some separatist claims. Specifically, the values that are central to republicanism might be furthered by political divorce resulting in two or more states whose citizens are better able than citizens of the previously unified state to consider the common good in their democratic deliberations.

Core principles of republicanism include a commitment to citizen participation in the deliberative process, made possible by civic virtue; the equality of political actors; and affirmation of the notion of a common interest or good. ${ }^{8}$ In principle, republicanism not only tolerates but assumes and even requires some measure of diversity within the self-governing polity. Republicanism rests on "a belief in the possibility of mediating different approaches to politics, or different conceptions of the public good, through discussion and dialogue," and sees disagreement as a creative force that promotes political deliberation. ${ }^{10}$ Republicanism regards the deliberative process itself as playing a central part in the constitution of political identity; through this process, initial preferences might be modified and, ideally, the outcome will promote a common—rather than a majority—good."

'See generally Frank I. Michelman, Conceptions of Democracy in American Constitutional Argument: Voting Rights, 41 FLA. L. REV. 443 (1989); Raskin, supra note 6, at 1453-54; Cass R. Sunstein, Beyond the Republican Revival, 97 YALE L.J. 1539 (1988).

'Sunstein, supra note 8, at 1554 (footnote omitted).

${ }^{10} \mathrm{See} i \mathrm{~d}$. at 1562,1575 . Sunstein argues that "[m]odern republicanism is thus not grounded in a belief in homogeneity; on the contrary, heterogeneity is necessary if republican systems are to work." Id. at 1576.

${ }^{15}$ See id. at $1554-56$. 
Yet this process requires not only "a commitment to political empathy, embodied in a requirement that political actors attempt to assume the position of those who disagree,"12 but a capacity to empathize with citizens whose interests may be different from one's own. The fabric of republicanism, like that of utilitarianism, might be strained by too much diversity within the polity. ${ }^{13}$

Similar considerations led John Stuart Mill to conclude that "it is in general a necessary condition of free institutions that the boundaries of government should coincide in the main with those of nationalities." 14 Indeed, the capacity to empathize was central to Mill's conception of nations:

A portion of mankind may be said to constitute a Nationality if they are united among themselves by common sympathies which do not exist between them and any others-which make them co-operate with each other more willingly than with other people, desire to be under the same government, and desire that it should be government by themselves or a portion of themselves exclusively. ${ }^{15}$

The claims of republicanism do not lead inexorably to a general rule favoring separatist claims. Cass Sunstein finds in republican principles themselves the potential for resolving problems posed by diversity through proportional representation rather than secession. ${ }^{16}$ More generally, institutional arrangements designed to promote interethnic accommodation can go a long way toward assuring cooperation in multiethnic societies.

But if the republican vision of democratic governance does not generally support separatist movements, neither is it irrelevant to their claims. In certain cases, such as when part of a population has become unalterably hostile to the interests of another major group in the same state, republican theories may point toward political divorce on the ground that separation would produce two states in which republican democracy is viable instead of one in which conditions are inauspicious for its successful practice.

Thus far I have offered examples of how democratic theories might support separatist claims. But other considerations, also derived from justifications for self-government or considerations relating to its successful practice, may point in the opposite direction. As President Lincoln argued, if a secessionist movement opposed by most of a country's citizens prevailed, its success would vitiate the principle of majority rule. Further, even the possibility of secession may thwart democratic deliberations by diminishing incentives for opposing groups to reach accommodative solutions. When secession is known to be possible, political minorities within a democracy can distort the outcome of political processes by threatening to secede if their views do not prevail. ${ }^{17}$

Further, a counterpoint to the claim that too much diversity may impair democratic deliberations is the argument that ethnonational states by their nature tend toward authoritarian social arrangements. Lord Acton described the threat this way: "In a small and homogeneous population there is hardly room . . . for inner groups of interests that set

${ }^{12} I d$. at 1555 (footnote omitted).

${ }^{13} \mathrm{Cf}$. id. at 1556 (observing that "the republican belief in deliberation about the common good is most easily sustained when there is homogeneity").

${ }^{14}$ MiLL, supra note 7, at 394.

${ }^{15} I d$. at 391 .

${ }^{16}$ See Sunstein, supra note 8, at 1588-89.

${ }^{17}$ See ALLEN BUCHANAN, SECESSION: THEMORALITY OF POLITICAL DIVORCE FROMFORT SUMTER TOLITHUANLA AND QUEBEC 100 (1991); Cass R. Sunstein, Constitutionalism and Secession, 58 U. CHI. L. REV. 633, 648-49 (1991). 
bounds to sovereign power." ${ }^{\text {18 }}$ In his view, the multiethnic state "provides against the servility which flourishes under the shadow of a single authority, by balancing interests, multiplying associations, and giving to the subject the restraint and support of a combined opinion." sure to find a corrective in the national diversities, which no other force could so efficiently provide. The coexistence of several nations under the same State is a test, as well as the best security of its freedom. ${ }^{, 20}$ If, with John Locke, we believe that the principle of selfgovernment follows from the intrinsic and equal worth of all people, it is plain that the authoritarian arrangements associated with ethnonational states imperil the core values justifying democratic government itself.

\section{Conclusion}

The implications of the "democratic entitlement" for separatist claims are at once profound and complex. Their very complexity calls for exceptional wisdom on the part of outside actors who may be called upon to respond to separatist claims.

${ }^{18}$ Lord Acton, Nationality, in ESSAYS ON FREEDOM AND POWER 141, 165 (1862, 1972).

${ }^{19} I d$ at 160 .

${ }^{20} I d$. 